\title{
Application of Very Low Frequency (VLF) Method for Estimating Karst Underground River in Tanjungsari District
}

\section{Muhammad Faizal Zakaria1, Sari Bahagiarti Kusumayudha², Bambang Prastistho², Istiana Rahatmawati $^{3}$, Tuti Setyaningrum ${ }^{4}$}

\author{
${ }^{1}$ Geophysical Engineering, Faculty of Mineral Technology, UPN Veteran Yogyakarta \\ ${ }^{2}$ Geological Engineering, Faculty of Mineral Technology, UPN Veteran Yogyakarta \\ ${ }^{3}$ Department of Management, Faculty of Economics and Business, UPN Veteran Yogyakarta \\ ${ }^{4}$ Department of Agrotechnology, Faculty of Agriculture, UPN Veteran Yogyakarta
}

\begin{abstract}
Drought is the main problem for clean water needs in Tanjungsari district. This research aims to provide information on the existence of underground river for deep well drilling. The methods used are geologic-structural analysis and application of Very Low Frequency (VLF) methods. Strike and dip measurements of 150 joints were conducted in the research area. Analysis using rosette diagram shows that the main geologic-structure orientation has a direction of Northwest - Southeast and Northeast - Southwest. Very Low Frequency (VLF) acquisition was measured across the possible occurrence of subsurface water flow directions predicted from geologicstructural analysis. The length of the VLF acquisition line is 2500 meters with $30 \mathrm{~m}$ spacing and 108 points acquisitions. The direction of VLF line is $\mathrm{N} 270^{\circ} \mathrm{E}$. The result shows that there are 2 locations that have high conductivity values, appearing at 1800 meters and 2200 meters. The results of this structural and VLF analyses indicate the existence of underground river at the location of $454326 \mathrm{~N}, 9105870 \mathrm{E}$.
\end{abstract}

Keywords: Tanjungsari, Underground River, VLF Method, Geologic Structure

This is an open access article under the CC-BY-NC license

\section{INTRODUCTION}

Tanjungsari District, Gunungkidul Regency, Yogyakarta Special Region is located in the southern part of Gunungkidul Regency, directly bordering with Indian Ocean. Drought occurs almost every year in this district. ${ }^{1-3}$ The lack of clean water in this district is due to the absence of adequate water below the surface of this area. The groundwater aquifer system in Tanjungari District is included in the karst aquifer system. ${ }^{4}$ Karst aquifers have more complex hydrogeological characteristic than sedimentary aquifer systems. ${ }^{5}$ The karst hydrogeological system has unique characteristics and is characterized by undeveloped surface aquifers. The development of karst landforms is dominated by secondary porosity caused by water dissolution. The development of karst causes the formation of subsurface water flows and makes surface karst hydrology less developed and less dominating. This is due to the appearance of cavities in the karst area, which makes it easy for water on the surface to enter underground. 5

The subsurface structure of the karst system is very complex ${ }^{6}$. For this reason, karst has become an attractive target for exploration in terms of geomorphology, geology, hydrogeology, geotechnic, environment, and geophysics. The most influential geological structures that form the lineaments of the surface topography in karst areas are joints, fractures and faults. The phenomenon of lineaments of the surface topography is very important to know because it can provide an early indication of the presence of subsurface water accumulation in karst areas. ${ }^{4}$. 
M. Faizal Zakaria, S. Bahagiarti Kusumayudha, B. Prastistho, I. Rahatmawati, T. Setyaningrum

The use of geophysical methods in the exploration of subsurface karst flows has been widely used in previous studies. Holub and Dumitrescu pioneered experiments using the Ground Penetrating Radar and Geoelectrical Mapping method for the detection of a $2 \mathrm{~km}$ tunnel in Switzerland. 7 . Zhou found evidence that the Self Potential method responds to subsurface rivers ${ }^{8}$. The Very Low Frequency (VLF) method is also widely used to detect subsurface caves in both empty (air-filled) ${ }^{9,10}$ and also water-filled cave. ${ }^{11-13}$

This study intends to determine the possibility of subsurface rivers in the karst area in Tanjungsari District geological-strutre analysis and VLF methods. The results of this study are expected to provide information about the position of the subsurface river, making it easier for the government to take water well through drilling.

\section{Gunungsewu Karst Hydrogeological System}

Tanjungsari District is included in the Gunungsewu Karst landscape. Gunungsewu karst is characterized by the presence of cone karst which is typical for the tropics. ${ }^{4}$ The formation that builds the Gunungsewu karst topography is the Gunungsewu Carbonate Rock Group or known as the Wonosari Formation.$^{14}$

Gunungsewu carbonate rock is positioned above the volcanic rock of The Besole Group, dominated by bedded limestone and reef limestone. The thickness of this limestone is thin to the north and getting thicker to the south. ${ }^{4}$ From the results of hydrogeological research on groundwater aquifers in the Karst area in Wonosari, the only aquifer that potential in the Gunungkidul area is the Wonosari Formation. ${ }^{14}$. In this formation, the permeability is dominated by secondary permeability which appears as complex cracks and fractures ${ }^{15}$. Kusumayudha divides the Gunungsewu hydrogeological system into 3 parts, called the Panggang sub-system in the west, the Wonosari-Baron sub-system in the middle, and the Sadeng sub-system in the east. Tanjungsari district is located in the WonosariBaron sub-system which is characterized by the presence of surface flow which then enters the subsurface (Figure 1). The thickness of the aquifer is $100 \mathrm{~m}$ to $400 \mathrm{~m}$, the type of aquifer is confined aquifer, unconfined aquifer, and perched aquifer in the rainy season. The underground flow pattern in the Wonosari-Baron sub-system is controlled by the fracture structure which has a larger fractal dimension than the other sub-systems. ${ }^{4}$

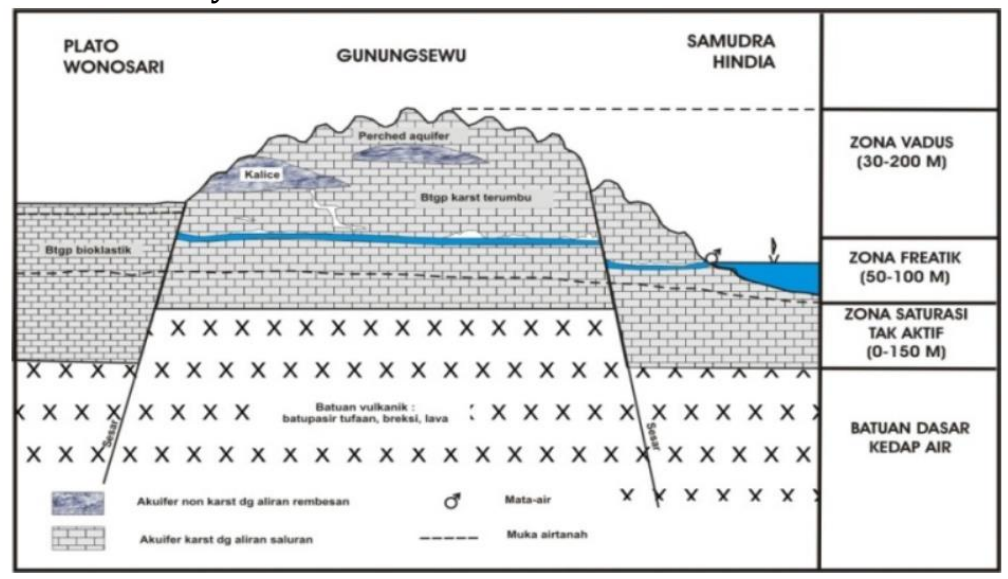

Figure 1. Wonosari-Baron Hydrogeological sub-system Conceptual Model 4

A subsurface flow map of the Wonosari-Baron sub-system can be made based on the study and analysis of the fracture structure traced from the lineament of aerial photographs, supported by the 
estimation results of the bedrock configuration using the gravity anomaly method, as shown in Figure 2. This underground flow pattern corresponds to the main channel river Bribin, with an average discharge of up to $900 \mathrm{l} / \mathrm{s}^{4}$ then form a Bribin drainage basin. Tanjungsari area is located in the Wonosari-Baron hydrogeological subsystem, and is expected to be crossed by the Bribin drainage basin that has an estuary at Baron Beach.

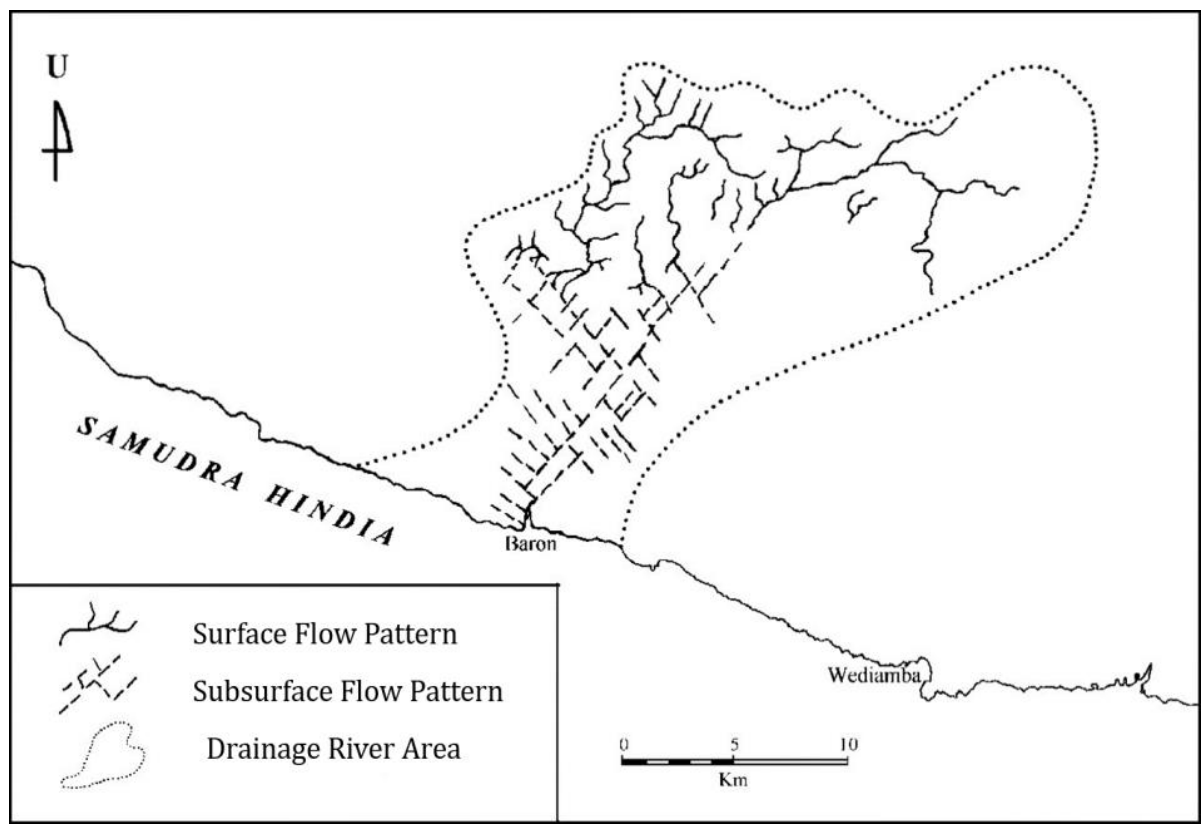

Figure 2. Subsurface flow map of the Wonosari-Baron sub-system ${ }^{4}$

\section{RESEARCH METHOD}

\section{Geologic-structural analysis}

In this study, in order to support the exact application of VLF method, geological structure analysis, especially cracks and joint, was also carried out. The joint structure data in the study area were obtained from the results of measuring the strike and dip of the joint on the exposed limestone in the field. Measurements were carried out statistically on 100 to 150 measurements, then plotted into a rose diagram, in order to obtain an overview of the general pattern of orientation of the fracture structure in the study area. The application of this geological structure analysis will at the same time be used to prove the validity of the subsurface flow pattern design map that has been made by Kusumayudha ${ }^{4}$.

\section{Very Low Frequency Method (VLF Method)}

The VLF method is a geophysical method that utilizes electromagnetic waves from radio signals. This radio signal has the main function as an underwater navigation signal and the transmitter of this signal is distributed all over the world. VLF data acquisition in this research used a transmitter from Ibino, Japan $(22000 \mathrm{~Hz})$. The direction of this transmitter is N $24 \mathrm{E}$ from the research area. The direction of the VLF acquisition line is $\mathrm{N} 270 \mathrm{E}$, and this line is perpendicular to the possible subsurface flow directions from structure analysis. The length of the VLF acquisition line is 2500 meters with $30 \mathrm{~m}$ spacing and 108 points acquisitions. Map of VLF line acquisition on the research area could be seen on figure 3 . This map includes the overlay map of the structure analysis result. 


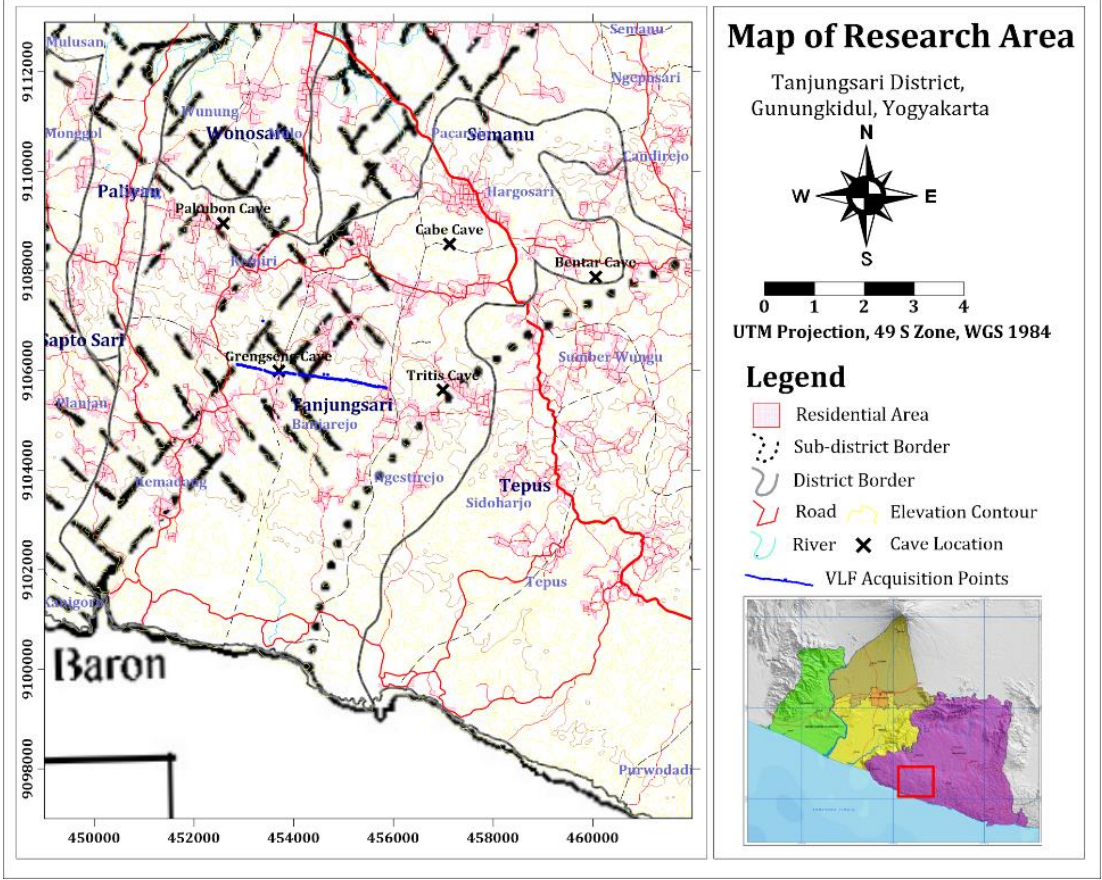

Figure 3. VLF Acquisition Map overlayed with the subsurface flow map

The presence of noise needs to be considered because the VLF method is very sensitive to local interference such as power line and also near surface conductive object around the measurement point. The measurement used T-VLF BGRM Iris Instrument. Field data shows a quality bar of the measurement result range between $70 \%-96 \%$. It shows that the data is in a good condition. The result of the measurement also shows that the field data is clear from overload magnetic field (SH). Only a few points measurement that show $\mathrm{SH}$ on the equipment.

Data obtained from the field is tilt values, ellipticity value, H-Hor value, and H-Ver Value. This data processed using Microsoft excel and KHFfilt software ${ }^{16}$ to get the current density cross section. The result of the pseudo section shows a low to high current density. This high value of current density means a relatively conductive medium and low current density means relatively resistive medium.

\section{RESULT AND DISCUSSION}

\section{Geologic-structural analysis}

The results of the strike and dip measurements of the 150 joint planes taken from limestone outcrops in the Gunungsewu karst of Gunungkidul Regency (52 joints measurement in the study area) showed a general pattern with the strike orientation ranging from $\mathrm{N} 300^{\circ} \mathrm{E}-\mathrm{N} 320^{\circ} \mathrm{E}$ and $\mathrm{N} 20^{\circ} \mathrm{E}-\mathrm{N} 70^{\circ} \mathrm{E}$, while the dip of joint planes are ranged from $30^{\circ}$ to $80^{\circ}$. The results of the plotting into a rosette diagram are shown in figure 4. 


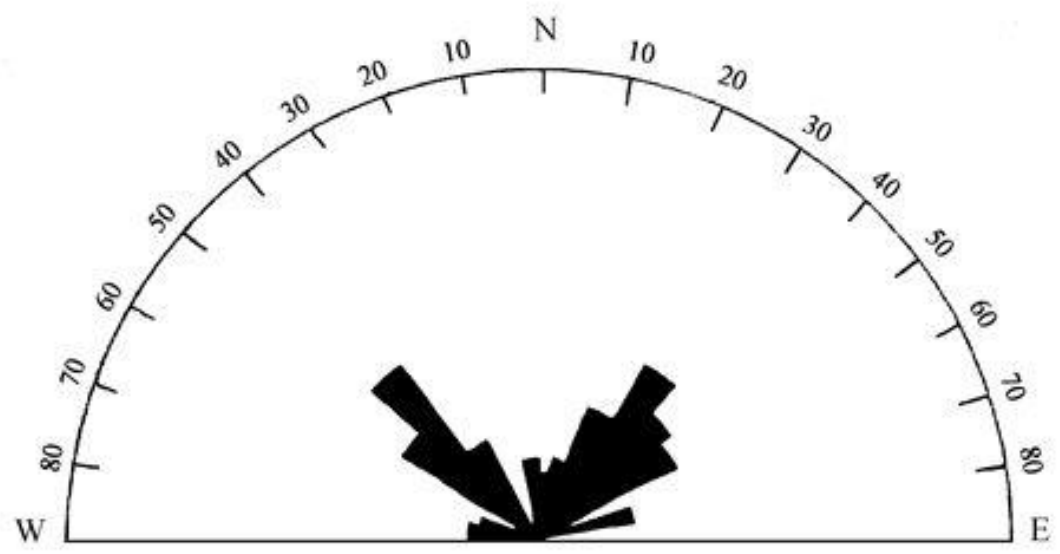

Figure 4. Result of rosette diagram, plot of strike and dip of the joint planes. Its shows that the general patterns are Northwest - Southeast and Northeast - Southwest.

Based on this study, it can be concluded that the fracture structure pattern in the Tanjungsari area has the main directions of Northwest - Southeast and Northeast - Southwest. This is in accordance with the design pattern of an underground river that has been made by Kusumayudha ${ }^{4}$. The orientation pattern of the main geological structure has a northwest-southeast and northeast-southwest direction, this indicates that the main stresses acting in the study area are north-south.

\section{Very Low Frequency Analysis}

Very Low Frequency method detects the presence of water filled cavity with indications of high current density values. Current Density is the highest possible current in the line acquisition. The value of the $t$ current density is relative to the value on the same line. A high current density value indicates that the area has a higher conductivity than its surroundings.

The results of the cross-section of the current density are shown in Figure 5. In this picture, the red color indicates the high current density value, the green color indicates the medium current density and the blue color indicates the low current density. The current density cross section is dominated by medium current density values and there are spots of high current density values (purple circle and red circle). A high current density value means it has a high conductivity medium. High conductivity is interpreted as the presence of subsurface cavities filled with water. This subsurface cavity filled with water is identified to be Bribin drainage basin that passes through the Tanjungsari district and has an estuary at Baron Beach.

There are 2 locations that have high conductivity values, appearing at 1800 meters (red circle), and 2200 (magenta circle). Based on the VLF acquisition map that has been overlaid with the structural analysis map, the first circle is right on the structural analysis line, the results of this structural and VLF analysis indicate the existence of the location subsurface flows at that location, $454326 \mathrm{~N}$, $9105870 \mathrm{E}$ (red circle figure 5). The river below the surface has a depth of approximately $200 \mathrm{~m}$. This depth is also confirmed by the conceptual model of the Wonosari-Baron sub-system which also shows that the subsurface river flows at a depth of approximately $200 \mathrm{~m}$. 


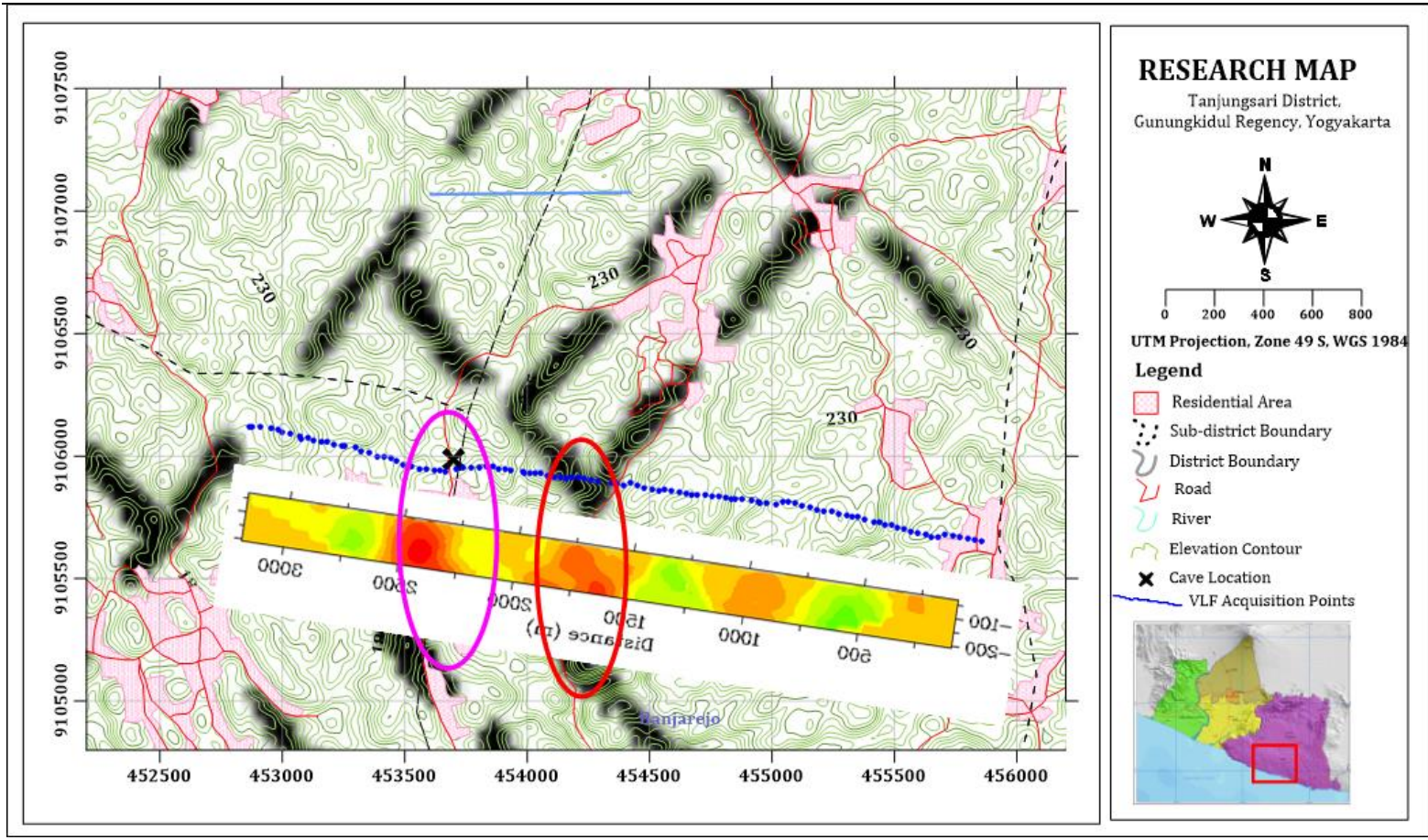

Figure 5. Cross section of Current density as the result of VLF Method, and overlaid in Subsurface Map.

The second high conductivity value, the second circle, is right where Grengseng Cave is located (magenta circle). Based on previous research, the depth that has been explored is only around $30 \mathrm{~m}$ along the side of the cave. So, the possibility of underground river flow under Grengseng Cave is quite high based on the results of the VLF analysis. The depth of this underground river is also approximately $200 \mathrm{~m}$.

\section{CONCLUSION}

The problem of drought in Tanjungsari District can be overcome using water well through drilling. Structural analysis and analysis of the VLF method can answer the existence of underground river locations in their needs for the exact location of subsurface water flow. Based on the structural analysis, the structure that controls the subsurface flow in the Tanjungsari district has the main direction of Northwest - Southeast and Northeast - Southwest. This means that the direction of the subsurface flow also has the same direction. The exact location of the presence of subsurface rivers can be known from the VLF method, which is at $454326 \mathrm{~N}, 9105870 \mathrm{E}$.

In order to know the subsurface flow in more detail throughout the Tanjungsari area, more VLF line are needed. To determine the depth of the flow more precisely, it is necessary to measure another geophysical method which is Geoelectric Sounding.

\section{ACKNOWLEDGEMENT}

The authors would like to thank the VLF survey team who helped make data acquisition at the research site and LPPM UPN "Veteran" Yogyakarta which funded this research.

\section{REFERENCES}

1. KRJOGJA. Kekeringan Landa Tanjungsari dan Girisubo. (2021).

2. kumparan.com. Kekeringan Landa 262 Pedukuhan di Gunungkidul. (2020). 
3. Nasional Tempo.co. Kekeringan Melanda 15 dari 18 Kecamatan di Gunungkidul. (2020).

4. Kusumayudha, S. B. Mengenal Hidrogeologi Karst. Pusat Studi Karst LPPM UPN “Veteran" Yogyakarta vol. 137 (2004).

5. Adji, T. N. \& Cahyadi, A. Pentingnya Monitoring Parameter-Parameter Hidrograf Dalam Pengelolaan Airtanah di Daerah Karst. (2017).

6. Goldscheider, N. \& Drew, D. Methods in Karst Hydrogeology: IAH: International Contributions to Hydrogeology, 26. (Crc Press, 2014).

7. Holub, P. \& Dumitrescu, T. Détection des cavités à l'aide de mesures électriques et du géoradar dans une galerie d'amenée d'eau. J. Appl. Geophys. 31, 185-195 (1994).

8. Wanfang, Z., Beck, B. F. \& Stephenson, J. B. Investigation of groundwater flow in karst areas using component separation of natural potential measurements. Environ. Geol. 37, 19-25 (1999).

9. Ogilvy, R. D., Cuadra, A., Jackson, P. D. \& Monte, J. L. DETECTION OF AN AIR-FILLED DRAINAGE GALLERY BY THE VLF RESISTIVITY METHOD1. Geophys. Prospect. 39, 845-859 (1991).

10. Guerin, R. \& Benderitter, Y. Shallow karst exploration using MT-VLF and DC resistivity methods1. Geophys. Prospect. 43, 635-653 (1995).

11. Bosch, F. P. \& Müller, I. Improved karst exploration by VLF-EM-gradient survey: comparison with other geophysical methods. Near Surf. Geophys. 3, 299-310 (2005).

12. Sismanto, M., Husein, S. \& Hartantyo, E. Subsurface River Flow Study in Oksibil of Pegunungan Bintang District by Very Low Frequency Electromagnetic Method. in International Conference on Physics 2014 (ICP-14) 100-104 (Atlantis Press, 2014).

13. Nugraha, E. D. \& Susanto, H. Application of vlf method to identify flow patterns of underground river in the karst area Ngargoharjo, Wonogiri. in Journal of Physics: Conference Series vol. 1170 12071 (IOP Publishing, 2019).

14. Kusumayudha, S. B., Zen, M. T., Notosiswoyo, S. \& Gautama, R. S. Fractal analysis of the Oyo River, cave systems, and topography of the Gunungsewu karst area, central Java, Indonesia. Hydrogeol. J. 8, 271-278 (2000).

15. Kusumayudha, S. B., Zakaria, M. F., Prastistho, B., Rahatmawati, I. \& Setyaningrum, T. The Potencies of Cave Geo-Ecotourism Development in Tanjungsari District, Gunungkidul Regency, Yogyakarta Special Region. in Proceeding of LPPM UPN “VETERAN” YOGYAKARTA CONFERENCE SERIES 2020-POLITICAL AND SOCIAL SCIENCE SERIES vol. 1 301-314 (2020).

16. Pirttijärvi, M. Karous-Hjelt and Fraser filtering of VLF measurements. Manual of the KHFFILT Program (2004). 